\title{
KELAYAKAN LKPD FISIKA BERBASIS PROBLEM SOLVING DALAM MENGUKUR KEMAMPUAN BERPIKIR KREATIF PESERTA DIDIK PADA MATERI FLUIDA STATIS
}

\author{
Ummu Kalsum ${ }^{1, a}$, Musdar $M^{2, b}$, Wahyuni Putri Awalia ${ }^{3, c}$ \\ ${ }^{1,2,3}$ Program Studi Pendidikan Fisika, Fakultas Keguruan dan Ilmu Pendidikan, Universitas Sulawesi Barat \\ e-mail: ummu.kalsum@unsulbar.ac.id ${ }^{\mathrm{a}}$ musdar@unsulbar.ac.id ${ }^{\mathrm{b}}$, wahyuniputria5@gmail.com $^{\mathrm{c}}$
}

\begin{abstract}
Abstrak
Penelitian ini bertujuan untuk menghasilkan media pembelajaran berupa LKPD Fisika berbasis Problem Solving yang layak digunakan dalam mengukur kemampuan berpikir kreatif peserta didik khususnya pada materi Fluida Statis. Penelitian ini merupakan penelitian $R \& D$ dengan desain penelitian mengacu pada 4-D yang dimodifikasi menjadi 3-D terdiri dengan tahapan: define, design, serta develop. Instrumen yang digunakan dalam pengumpulan data penelitian meliputi lembar validasi, angket respon peserta didik, angket respon guru. Pengujian LKPD Fisika dilakukan kepada 20 peserta didik kelas XI MIPA 3 SMAN. 1 Majene. Hasil penelitian menunjukkan bahwa: (1) LKPD Fisika berbasis problem solving telah memenuhi kriteria sangat valid berdasarkan hasil validasi para ahli (2) LKPD berbasis problem solving berada pada kategori sangat praktis berdasarkan hasil pengisian angket respon peserta didik dan respon guru (3) LKPD berbasis problem solving cukup efektif digunakan untuk mengukur kemampuan berpikir kreatif peserta didik dengan rata-rata perolehan sebesar 67 yang berada pada kategori cukup kreatif.
\end{abstract}

Kata Kunci: LKPD Fisika, Problem Solving, Kemampuan Berpikir Kreatif, Fluida Statis

\section{FEASIBILITY OF PHYSICS LKPD BASED ON PRONLEM SOLVING IN MEASURING CREATIVE THINKING ABILITY OF STUDENTS ON STATIC FLUID MATERIAL}

\begin{abstract}
This study aims to produce learning media in the form of Problem Solving-based Physics worksheets that are suitable to be used in measuring students' creative thinking skills, especially in Static Fluids. This research is an $\mathrm{R} \& \mathrm{D}$ research with research design referring to 4-D which is modified into 3-D consisting of the stages: define, design, and develop. The instruments used in collecting research data include validation sheets, student response questionnaires, teacher response questionnaires. Physics LKPD testing was carried out on 20 students of class XI MIPA 3 SMAN. 1 Majene. The results showed that: (1) problem solving-based Physics LKPD had met the very valid criteria based on the results of the validation of experts (2) problem solving-based LKPD was in the very practical category based on the results of filling out student response questionnaires and teacher responses (3) problem solving is effective enough to be used to measure students' creative thinking skills with an average acquisition of 67 which is in the category of creative enough
\end{abstract}

Keywords: Students Worksheet, Problem Solving, Creative Thinking, Static Fluid 


\section{PENDAHULUAN}

Dewasa ini, kompetensi dalam dunia kerja semakin tinggi dengan tuntutan kemampuan inovasi dan kreativitas dari sumber daya manusia. Bahkan beberapa perusahaan seperti Samsung, Microsoft dan Toyota melakukan rekrutmen karyawan dengan kualifikasi kemampuan inovasi, kreatifitas, menyelesaikan masalah, komunikasi, keterampilan sosial, dan penguasaan teknologi informasi. Berdasarkan tuntutan pasar kerja maka dibutuhkan sumber daya manusia yang mampu berpikir kreatif, berpikir kritis, mampu berkomunikasi dan berkolaborasi. Olehnya itu, sekolah sebagai wadah untuk membekali peserta didik menjadi sumber daya berkualitas harus mampu menciptakan lulusan dengan kemampuan berpikir tingkat tinggi meliputi berpikir kreatif, kritis dan kemampuan memecahkan masalah [1]. (Sani, Abdullah ridwan, et. Al. 2019)

Salah satu dari kemampuan berpikir tingkat tinggi yang penting untuk dikaji dan dikembangkan pada tataran pembelajaran di kelas adalah kemampuan berpikir kreatif. Peserta didik yang memiliki kemampuan berpikir kreatif mampu menciptakan ide-ide dalam menyempurnakan produk/ karya yang sudah ada [2]. Bahkan, peserta didik tersebut dapat menciptakan sesuatu yang baru dan unik. Selain itu, peserta didik dilatih agar memiliki sensitivitas dalam menyelesaikan permasalahan dengan menemukan kemungkinan solusi penyelesaian.

Berdasarkan perilaku peserta didik dalam menyelesaikan permasalahan yang diberikan pada pembelajaran di kelas maka tentunya dapat berdampak pada peningkatan prestasi belajar dan kemampuan berpikir kreatif peserta didik [3]. Hal ini disebabkan karena peserta didik yang memiliki tingkat kemampuan berpikir kreatif tinggi memiliki motivasi sehingga semangat dalam belajar.
Jika dipandang dalam bingkai kurikulum K13, kemampuan berpikir kreatif juga menjadi salah satu tuntutan yang harus dikembangkan dalam pembelajaran di kelas misalnya mata pelajaran fisika. Fisika sebagai ilmu yang mengkaji fenomena alam dan gejalanya diharapkan mampu melatih sisi kreatif peserta didik. Pada proses pembelajaran fisika, peserta didik diberikan permasalahan yang dapat diselesaikan dengan berbagai cara penyelesaian. Dengan kata lain, dalam menyelesaikan permasalahan fisika dibutuhkan kemampuan berpikir kreatif. Ironi yang terjadi adalah masih kurangnya kemampuan berpikir kreatif peserta didik dalam pembelajaran fisika.

Fenomena yang serupa juga ditemukan di SMA Negeri 1 Majene. Berdasarkan hasil observasi diketahui bahwa peserta didik kurang kreatif dalam menyelesaikan permasalahan khususnya dalam pembelajaran fisika. Hal ini tergambar dari aktivitas peserta didik selama pembelajaran berlangsung. Aktivitas yang dimaksud diantaranya; (1) peserta didik dalam menjawab pertanyaan guru, hanya memberikan pernyataan sesuai dengan buku. Dengan kata lain, jawaban peserta didik bersifat text book sehingga tidak ditemukannya adanya ungkapan baru dari pernyataan jawaban yang diberikan. (2) Peserta didik dalam mengerjakan soal membutuhkan waktu yang lama. Lamanya waktu pengerjaan soal menunjukkan ketidakmampuan dalam mengungkapkan ide-ide penyelesaian secara lancar. Bahkan beberapa diantaranya tidak dapat menyelesaikan soal secara keseluruhan. (3) kurangnya kemampuan peserta didik dalam mengelaborasi konsep fisika sehingga tidak dapat dalam mengembangkan gagasan baru. Hal ini nampak saat memformulasi persamaan fisika, peserta didik tidak dapat memberikan penurunan secara terperinci terkait persamaan dasar yang digunakan. Keseluruhan aktivitas peserta didik yang 
telah dijabarkan ini memberikan dampak pada nilai ulangan harian dimana $80 \%$ peserta didik memiliki nilai dibawah kriteria ketuntasan minimal (KKM).

Jika ditelusuri lebih jauh penyebab fenomena ini diantaranya; proses pembelajaran fisika yang terjadi belum melatih kemampuan berpikir kreatif peserta didik dengan dominasi peran guru sebagai sumber ilmu, nampak bahwa peserta didik cenderung menghapal rumus fisika tanpa memahami konsep dan maknanya, media pembelajaran yang digunakan kurang menarik sehingga perhatian peserta didik teralihkan untuk melakukan aktivitas lain. Hal ini diketahui dari hasil wawancara dengan beberapa peserta yang mengungkapkan bahwa alasan dilakukan aktivitas seperti bercerita dengan teman sebangku, keluar masuk kelas dan aktivitas lainnya yang tidak berhubungan dengan pembelajaran adalah munculnya rasa bosan karena media pembelajaran yang digunakan guru kurang menarik.

Berangkat dari permasalahan kurangnya kreativitas serta daya tarik peserta didik terhadap media pembelajaran maka dibutuhkan sebuah solusi. Salah satu alternatif solusi yang dimaksud adalah penggunaan media pembelajaran berupa lembar kerja peserta didik (LKPD). LKPD ini digunakan sebagai panduan peserta didik dalam melakukan kegiatan penyelidikan untuk memecahkan masalah yang diberikan dalam pembelajaran fisika. LKPD merupakan lembar kerja yang sengaja dirancang agar peserta didik dapat mengerjakan tugas dalam suatu pembelajaran [4]. Pemilihan LKPD dipandang efektif karena peserta didik dapat berperan aktif dalam proses pembelajaran sementara guru bertindak mengarahkan. Fungsi penggunaan LKPD diantaranya: sebagai bahan ajar yang dapat meminimalkan peran guru dalam pembelajaran serta lebih mengaktifkan peserta didik, sebagai petunjuk bagi peserta didik untuk mengerjakan tugas yang diberikan, dan memperlancar jalannya pembelajaran [5].

Selain penggunaan LKPD, solusi permasalahan yang ditawarkan adalah pembelajaran dengan metode problem solving. Penyajian LKPD berbasis problem solving sebagai bentuk inovasi yang dilakukan dalam penelitian ini. Menurut Polya (1947) dalam Nurliawaty, et al. (2017) langkah-langkah metode problem solving yaitu: memahami masalah (understanding), menentukan rencana strategi pemecahan masalah (planning), menyelesaikan strategi pemecahan masalah (solving), memeriksa kembali jawaban (cheking) [6].

Berdasarkan langkah-langkah metode Problem solving maka dipandang dapat melatih kemampuan berpikir kreatif peserta didik dalam pembelajaran fisika. Penerapan pembelajaran problem solving memiliki pengaruh terhadap kemampuan berpikir kreatif siswa [7]. Hal ini terlihat dari nilai rata-rata kemampuan berpikir kreatif peserta didik yang diajar dengan metode problem solving lebih baik dari pembelajaran konvensional.

Beberapa penelitian pendukung yang telah dikemukakan sebelumnya menunjukkan bahwa terdapat pengaruh metode problem solving terhadap kemampuan berpikir kreatif. Olehnya itu, peneliti tertarik untuk mengkaji bagaimana membuat sebuah LKPD berbasis problem solving dalam mengukur kemampuan berpikir kreatif peserta didik khususnya pada materi fluida statis. LKPD yang dibuat ini tentunya memenuhi memenuhi kriteria valid, praktis serta efektif dalam penggunaannya. Dengan demikian, judul dari penelitian ini adalah "Kelayakan LKPD Fisika Berbasis Problem Solving Dalam Mengukur Kemampuan Berpikir Kreatif Peserta Didik Pada Materi Fluida Statis".

\section{METODE PENELITIAN}




\section{.1 Jenis penelitian}

Jenis penelitian ini menggunakan jenis penelitian dan pengembangan (Research and Development) yang bertujuan untuk menghasilkan produk tertentu, dan menguji kelayakan produk tersebut. Penelitian R\&D merupakan metode penelitian yang menghasilkan produk tertentu, dan menguji keefektifan dari produk tersebut [8]. Untuk dapat menghasilkan produk pengembangan yang efektif sehingga dapat digunakan pada masyarakat luas diperlukan analisis kebutuhan dan pengujian kelayakan produk

Dalam penelitian ini, produk yang dimaksud berupa LKPD Fisika berbasis problem solving tersebut.

\section{2 Subjek Penelitian}

Subjek penelitian merupakan peserta didik kelas XI MIPA 3 SMA Negeri 1 Majene dengan jumlah sebanyak 20 orang.

\subsection{Desain Penelitian}

Desain penelitian yang digunakan menggunakan model 4-D yang dimodifikasi menjadi 3-D. Modifikasi dilakukan dengan pertimbangan keterbatasan waktu dan tujuan penelitian sudah tercapai pada tahap pengembangan. Model 3-D yang digunakan meliputi tahapan antara lain; pendefinisian (define), perancangan (design), dan pengembangan (develop)..

\subsection{Prosedur Penelitian}

Prosedur penelitian didasarkan pada tahapan dari model 3-D. dengan rincian sebagai berikut :

\subsubsection{Tahap pendefinisian (define)}

a) Analisis awal-akhir

Analisis awal akhir merupakan suatu proses penetapan permasalahan yang akan dicarikan solusi penyelesaian. Berdasarkan masalah yang dihadapi pada pembelajaran fisika khususnya di SMA Negeri 1 Majene maka solusi alternatif yang diberikan berupa penggunaan media pembelajaran LKPD yang relevan dengan mempertimbangkan beberapa hal diantaranya teori belajar, tantangan dan tuntutan masa depan.

b) Analisis peserta didik

Analisis dilakukan dengan mengumpulkan informasi terkait karakteristik peserta didik meliputi perkembangan kognitif dan latar belakang akademik. .

c) Analisis materi

Analisis materi ini merupakan dasar dari penyusunan bahan LKPD Fisika. Pemilihan materi disesuaikan tujuan pembelajaran serta pencapaian kompetensi dasar. Materi yang dipilih adalah fluida statis dengan pertimbangan terdapat berbagai percobaan untuk tiap bagian materi yang memungkinkan dilakukan peserta dengan bahan yang mudah didapatkan di lingkungan sekitar

d) Analisi tugas

Tugas yang diberikan pada LKPD Fisika mengacu pada kompetensi dasar dan indikator pencapaian pada materi ajar yang ditetapkan Kemendikbud pada satuan pendidikan SMA.

e) Spesifikasi tujuan pembelajaran

Pada tahap ini diawali dengan melakukan penjabaran kompetensi dasar ke dalam indikator yang lebih spesifik dan berdasarkan hasil analisis materi serta analisis tugas. Selanjutnya dilakukan pengembangan media pembelajaran yang disusun berdasarkan hasil analisis materi pembelajaran.

2.4.2 Tahap perancangan (design)

a) Pemilihan media

Media yang dipilih didasarkan pada tujuan pembelajaran, karakteristik peserta didik, strategi belajar mengajar, fungsi media serta kemampuan guru. Media yang dimaksud dalam penelitian ini adalah LKPD Fisika.

b) Pemilihan format

Pada tahap ini format yang digunakan berupa ukuran kertas A4. Jenis tulisan terdiri atas Britannic Bold, Times New Roman (Headings CS), One Stroke Script LET dengan ukuran font 14. Pada LKPD juga disajikan gambar yang bertujuan menarik perhatian pembaca. 
c) Rancangan awal

Desain awal dari media pembelajaran berupa Lembar Kerja Peserta didik (LKPD) yang dikembangkan berdasarkan tahapan dari problem solving. Rancangan media yang dihasilkan selanjutkan akan diserahkan ke validator untuk dinilai.

\subsubsection{Tahap pengembangan (develop)}

a) Validasi ahli

Hasil rancangan LKPD dinilai oleh validator. Berdasarkan saran dari ketiga validator maka dilakukan revisi demi kesempurnaan LKPD Fisika. .

b) Uji coba

Uji coba dilakukan dengan menyebarkan LKPD Fisika kepada peserta didik. Uji coba ini bertujuan mengukur kemampuan berpikir kreatif peserta didiK.

\subsection{Instrumen Penelitian}

Instrumen penelitian merupakan alat yang digunakan untuk mengukur fenomena alam maupun sosial [8]. Instrumen penelitian digunakan untuk mengambil data yang dibutuhkan pada suatu penelitian. Adapun instrumen penelitian yang digunakan diuraikan sebagai berikut: Tabel 3.1 Instrumen Penelitian

\begin{tabular}{|c|c|c|c|}
\hline $\begin{array}{c}\text { No } \\
\text {. }\end{array}$ & Data & $\begin{array}{c}\text { Sumber } \\
\text { Data }\end{array}$ & $\begin{array}{l}\text { Instrumen } \\
\text { Penelitian }\end{array}$ \\
\hline 1. & $\begin{array}{l}\text { Kemampuan } \\
\text { berpikir } \\
\text { kreatif } \\
\text { peserta didik. }\end{array}$ & $\begin{array}{l}\text { Peserta } \\
\text { didik }\end{array}$ & $\begin{array}{l}\text { Terintegrasi } \\
\text { dalam LKPD }\end{array}$ \\
\hline 2. & $\begin{array}{l}\text { Penilaian } \\
\text { ahli/validasi }\end{array}$ & $\begin{array}{c}\text { Ahli } \\
\text { media }\end{array}$ & $\begin{array}{l}\text { Angket } \\
\text { validasi ahli } \\
\text { media }\end{array}$ \\
\hline 3. & $\begin{array}{l}\text { Respon } \\
\text { peserta didik } \\
\text { terhadap } \\
\text { LKPD Fisika }\end{array}$ & $\begin{array}{l}\text { Peserta } \\
\text { didik }\end{array}$ & $\begin{array}{l}\text { Angket } \\
\text { respon } \\
\text { peserta didik }\end{array}$ \\
\hline 4. & $\begin{array}{l}\text { Respon guru } \\
\text { terhadap } \\
\text { LKPD Fisika }\end{array}$ & $\begin{array}{c}\text { Guru } \\
\text { mata } \\
\text { pelajaran } \\
\text { fisika }\end{array}$ & $\begin{array}{l}\text { Angket } \\
\text { Respon Guru }\end{array}$ \\
\hline
\end{tabular}

2.6 Teknik analisis data
Teknik analisis data yang digunakan dalam penelitian ini dijabarkan sebagai berikut:

2.6.1 Analisis Data Kevalidan

Kevalidan produk penelitian dinilai oleh tiga validator yang ahli dalam penyusunan media pembelajaran. Adapun Persentase rata-rata tiap komponen dihitung menggunakan rumus sebagai berikut

$$
\mathrm{P}=\frac{f}{N} \times 100 \%
$$

Keterangan:

$$
\mathrm{P}=\text { Persentase skor }
$$

$f=$ Perolehan skor

$\mathrm{N}=$ Skor maksimum

Penentuan tingkat validitas didasarkan pada kriteria berikut:

Tabel 3.5 Kriteria Penilaian Data Kevalidan

\begin{tabular}{cc}
\hline $\begin{array}{c}\text { Persentase } \\
\text { Kevalidan }\end{array}$ & Kategori \\
\hline $81-100$ & Sangat Valid \\
\hline $61-80$ & Valid \\
\hline $41-60$ & Kurang Valid \\
\hline $21-40$ & Tidak Valid \\
\hline $0-20$ & $\begin{array}{c}\text { Sangat Tidak } \\
\text { Valid }\end{array}$ \\
\hline
\end{tabular}

[10]

\subsubsection{Analisis Data Kepraktisan}

Data kepraktisan diperoleh dari angket respon guru dan peserta didik. LKPD Fisika yang dikembangkan dikatakan memenuhi kriteria kepraktisan apabila guru dan peserta didik menunjukkan respon positif terhadap penggunaan LKPD. Pada kedua angket digunakan skala Likert dengan kategori sebagai berikut:

Tabel 3.6 Kategori Penilaian Skala Likert

\begin{tabular}{lcc}
\hline No & Skor & Keterangan \\
\hline 1 & Skor 5 & Sangat setuju (SS) \\
\hline 2 & Skor 4 & Setuju (S) \\
\hline 3 & Skor 3 & Ragu-ragu (RR) \\
\hline 4 & Skor 2 & Tidak setuju (TS) \\
\hline 5 & Skor 1 & $\begin{array}{c}\text { Sangat tidak setuju } \\
\text { (STS) }\end{array}$ \\
\hline
\end{tabular}


Pengambilan keputusan dalam menentukan kepraktisan LKPD Fisika menggunakan kriteria kualifikasi penilaian yang ditunjukkan pada tabel 3.7 sebagai berikut:

Tabel 3.7 Kriteria Penilaian Data Kepraktisan

\begin{tabular}{cc}
\hline $\begin{array}{c}\text { Persentase } \\
\text { Kepraktisan }\end{array}$ & Kategori \\
\hline $81-100$ & Sangat Praktis \\
\hline $61-80$ & Praktis \\
\hline $41-60$ & Kurang Praktis \\
\hline $21-40$ & Tidak Praktis \\
\hline $0-20$ & Sangat Tidak Praktis \\
\hline &
\end{tabular}

\subsubsection{Analisis Data Keefektifan}

Keefektifan LKPD Fisika dilihat dari capaian kemampuan berpikir kreatif peserta didik setelah mengisi LKPD. Nilai dari pengerjaan soal pada LKPD dikoversi dari bentuk skor dengan menggunakan persamaan sebagai berikut :

$$
\text { Nilai }=\frac{\text { skor riil }}{\text { skor maksimum ideal }} \times 100
$$

Adapun tingkat kemampuan berpikir kreatif peserta didik menggunakan kriteria sebagai berikut :

\begin{tabular}{cc}
\hline $\begin{array}{c}\text { Keberhasilan } \\
\text { Tindakan }(\boldsymbol{\%})\end{array}$ & Kriteria \\
\hline $95 \leq \mathrm{PK} \leq 100$ & Sangat Kreatif \\
\hline $80 \leq \mathrm{PK}<95$ & Kreatif \\
\hline $65 \leq \mathrm{PK}<80$ & Cukup Kreatif \\
\hline $55 \leq \mathrm{PK}<65$ & Kurang Kreatif \\
\hline $\mathrm{PK}<55$ & Tidak Kreatif \\
\hline
\end{tabular}

\section{HASIL PENELITIAN}

\subsection{Validasi}

Validasi Instrumen penelitian dilakukan dengan menggunakan validasi ahli. Dalam hal ini validator yang menilai sebanyak 3 orang. Adapun hasil analisis dari ketiga validator ditunjukkan pada tabel 3.1 berikut

Tabel 3.1 Data hasil validasi LKPD

\begin{tabular}{clcc}
\hline No & \multicolumn{1}{c}{ Aspek } & Penilaian & Keterangan \\
\hline 1 & Format & $93,75 \%$ & Sangat valid \\
\hline 2 & Bahasa & $93,75 \%$ & Sangat valid \\
\hline 3 & Isi & $92,67 \%$ & Sangat valid \\
\hline & $\begin{array}{l}\text { Ilustasi dan } \\
\text { tata letak } \\
\text { diagram }\end{array}$ & $87,50 \%$ & Sangat valid \\
\hline 5 & Waktu & $83,33 \%$ & Sangat valid \\
\hline & Rata-rata & $90,2 \%$ & $\begin{array}{c}\text { SANGAT } \\
\text { VALID }\end{array}$ \\
\hline & & &
\end{tabular}

Selanjutnya angket respon peserta didik divalidasi dengan hasil analisis dari ketiga validator sebagai berikut :

Tabel 3.2 Data hasil validasi angket respon Peserta Didik

\begin{tabular}{cccc}
\hline No & Aspek & Penilaian & Keterangan \\
\hline 1 & Format & $100 \%$ & Sangat valid \\
\hline 2 & Bahasa & $97,91 \%$ & Sangat valid \\
\hline 3 & Isi & $100 \%$ & Sangat valid \\
\hline $\begin{array}{c}\text { Rata- } \\
\text { rata }\end{array}$ & $99,3 \%$ & $\begin{array}{c}\text { SANGAT } \\
\text { VALID }\end{array}$ \\
\hline
\end{tabular}

Sementara untuk respon guru sebagai pengguna diperoleh hasil analisis validasi sebagai berikut :

Tabel 3.3 Data hasil validasi angket respon Guru

\begin{tabular}{cccc}
\hline No & Aspek & Penilaian & Keterangan \\
\hline 1 & Format & $97,22 \%$ & Sangat valid \\
\hline 2 & Bahasa & $91,67 \%$ & Sangat valid \\
\hline 3 & Isi & $100 \%$ & Sangat valid \\
\hline & $\begin{array}{c}\text { Rata- } \\
\text { rata }\end{array}$ & $96,29 \%$ & $\begin{array}{c}\text { SANGAT } \\
\text { VALID }\end{array}$ \\
\hline
\end{tabular}

\subsection{Data kepraktisan}

Data kepraktisan LKPD Fisika berbasis problem solving diperoleh dengan cara membagikan angket respon peserta didik yang telah dinyatakan valid sebelumnya. Responden yang digunakan sebanya 20 orang yang berasal dari kelas XI MIPA 3 SMAN. 1 Majene

Tabel 3.4 Data analisis angket respon Peserta Didik 


\begin{tabular}{clcc}
\hline No & \multicolumn{1}{c}{ Aspek } & Penilaian & Keterangan \\
\hline 1 & Penyajian & $86,14 \%$ & Sangat valid \\
\hline 2 & Penggunaan & $88,25 \%$ & Sangat valid \\
\hline 3 & Keterbacaan & $87,33 \%$ & Sangat valid \\
\hline 5 & Waktu & $83,00 \%$ & Sangat valid \\
\hline & Rata-rata & $86,18 \%$ & $\begin{array}{c}\text { SANGAT } \\
\text { VALID }\end{array}$ \\
\hline
\end{tabular}

Selain dibagikan kepada peserta didik, data kepraktisan dari LKPD Fisika berbasis problem solving juga dibagikan kepada guru sebagai pengguna. Hal ini dilakukan untuk melihat respon guru terhadap penggunaan LKPD dalam pembelajaran. Guru yang dimaksud sebanyak 2 orang yang merupakan guru mata pelajaran fisika pada SMAN. 1 Majene. Berdasarkan hasil analisis data diketahui

Tabel 3.5 Data analisis angket respon Peserta Didik

\begin{tabular}{clcc}
\hline No & \multicolumn{1}{c}{ Aspek } & Penilaian & Keterangan \\
\hline 1 & Penyajian & $85,71 \%$ & Sangat valid \\
\hline 2 & Penggunaan & $90 \%$ & Sangat valid \\
\hline 3 & Keterbacaan & $80 \%$ & Sangat valid \\
\hline 5 & Waktu & $85 \%$ & Sangat valid \\
\hline & Rata-rata & $85,17 \%$ & $\begin{array}{c}\text { SANGAT } \\
\text { VALID }\end{array}$ \\
\hline
\end{tabular}

\subsection{Data Keefektifan}

Data keefektifan LKPD berbasis problem solving ditinjau dari perolehan kemampuan berpikir kreatif peserta didik setelah mengerjakan LKPD. Berikut Hasil perolehan kemampuan berpikir kreatif tiap peserta didik:

Tabel 3.6 Kemampuan berpikir kreatif Peserta Didik

\begin{tabular}{cccc}
\hline No. & Responden & $\begin{array}{c}\text { Kemampuan } \\
\text { Berpikir } \\
\text { Kreatif }\end{array}$ & $\begin{array}{c}\text { Kategori } \\
\text { Kemampuan } \\
\text { Berpikir Kreatif }\end{array}$ \\
\hline 1. & PD 1 & 65 & Cukup Kreatif \\
\hline 2. & PD 2 & 67 & Cukup Kreatif \\
\hline 3. & PD 3 & 63 & Cukup Kreatif \\
\hline 4. & PD 4 & 58 & Kurang Kreatif \\
\hline 5. & PD 5 & 83 & Kreatif \\
\hline 6. & PD 6 & 62 & Kurang Kreatif \\
\hline 7. & PD 7 & 79 & Cukup Kreatif \\
\hline 8. & PD 8 & 65 & Cukup Kreatif \\
\hline 9. & PD 9 & 75 & Cukup Kreatif \\
\hline
\end{tabular}

\begin{tabular}{|c|c|c|c|}
\hline No. & Responden & $\begin{array}{c}\text { Kemampuan } \\
\text { Berpikir } \\
\text { Kreatif } \\
\end{array}$ & $\begin{array}{c}\text { Kategori } \\
\text { Kemampuan } \\
\text { Berpikir Kreatif }\end{array}$ \\
\hline 10. & PD 10 & 58 & Kurang Kreatif \\
\hline 11. & PD 11 & 65 & Cukup Kreatif \\
\hline 12. & PD 12 & 69 & Cukup Kreatif \\
\hline 13. & PD 13 & 65 & Cukup Kreatif \\
\hline 14. & PD 14 & 79 & Cukup Kreatif \\
\hline 15. & PD 15 & 67 & Cukup Kreatif \\
\hline 16. & PD 16 & 71 & Cukup Kreatif \\
\hline 17. & PD 17 & 63 & Cukup Kreatif \\
\hline 18. & PD 18 & 65 & Cukup Kreatif \\
\hline 19. & PD 19 & 67 & Cukup Kreatif \\
\hline \multirow[t]{3}{*}{20.} & PD 20 & 52 & Tidak Kreatif \\
\hline & Jumlah & 1338 & \\
\hline & Rata-rata & 67 & Cukup Kreatif \\
\hline
\end{tabular}

\section{PEMBAHASAN}

Kelayakan LKPD Fisika Berbasis problem ditinjau dari tiga kriteria meliputi validasi, kepraktisan dan keefektifan. Secara rinci penjelasan ketiga kriteria kelayakan diuraikan sebagai berikut :

\section{Data validasi}

Instrumen yang digunakan dalam penelitian ini terdiri atas LKPD Fisika berbasis problem solving, angket respon peserta didik dan angket respon. Suatu instrumen penelitian dinyatakan valid ketika para ahli (expert) meyakini kemampuan instrumen untuk mengukur penguasaan serta konstruk psikologi yang didefinisikan dalam instrumen tersebut [13]

Berdasar pada acuan tersebut, ketiga instrumen penelitian telah dinilai oleh ketiga ahli. Hasil penilaian ketiga validator dianalisis dengan menggunakan persamaan Prof. Dr. Suharsimi Arikunto yang memberikan hasil bahwa rata-rata validasi LKPD sebesar 90,20\%, angket respon peserta didik sebesar 99,30\% dan respon guru 96,29\%. Jika ketiga hasil ini dirataratakan kembali maka diperoleh 95\% dengan kategori sangat valid.

Ketiga hasil tersebut diperoleh merupakan nilai rata-rata dari masing-masing aspek pengukuran. Jika nilai rata-rata dari ketiga instrumen diklasifikasikan dalam tingkatan validitas maka diperoleh kategori sangat valid. Hasil ini bermakna bahwa ketiga 
instrumen dapat digunakan dalam penelitian ini. Hal ini didukung oleh ungkapan dari ketiga validator yang menyatakan bahwa ketiga instrumen dapat diterapkan dengan revisi kecil.

\section{Data kepraktisan}

Data kepraktisan dalam penelitian ini ditinjau dari hasil isian angket respon peserta didik dan respon guru. Nilai kepraktisan dari suatu produk didasarkan pada tingkat kemudahan dalam penggunaan [14]. Dalam kasus ini, pengguna yang dimaksud adalah peserta didik dan guru mata pelajaran.

Berdasarkan hasil pengisian angket respon peserta didik maupun angket respon guru diketahui bahwa rata-rata penilaian untuk keempat aspek sebesar 86,18\%, dan $85,17 \%$. Jika nilai rata-rata tersebut diklasifikasikan dalam tingkatan kepraktisan maka keduanya menunjukkan tingkatan sangat praktis. Hasil ini memiliki makna bahwa berdasarkan penilaian peserta didik dan guru mata pelajaran fisika maka LKPD Fisika berbasis problem solving sangat praktis digunakan dalam pembelajaran.

\section{Keefektifan}

Data keefektifan dari LKPD Fisika berbasis problem solving ditinjau dari kemampuan berpikir kreatif peserta didik setelah mengisi LKPD. Secara klasikal, rata-rata perolehan kemampuan berpikir kreatif peserta didik sebesar 67. Jika hasil ini diklasifikan dalam tingkatan kemampuan berpikir kreatif maka diperoleh kategori cukup kreatif. Hal ini disebabkan sebagian peserta didik dalam mengisi item rancangan percobaan pada LKPD telah menuliskan dua percobaan dengan desain yang sedikit berbeda dengan desain yang telah ada.Selain itu, alat dan bahan yang dipilih dalam rancangan percobaan sudah bervariasi. Akan tetapi, peserta didik dalam memformulasikan persamaan fisika masih sesuai dengan buku bacaan. Dalam hal ini, peserta didik tidak merinci secara detail persamaan dasar fisika yang digunakan dalam penjabaran. Dengan demikian, sebagian besar peserta didik memiliki kemampuan berpikir kreatif yang berada pada kategori cukup kreatif.

Jika ditelusuri lebih jauh alasan LKPD Fisika berbasis problem solving dapat melatih kemampuan berpikir kreatif peserta didik adalah setiap tahapan dari problem solving yang disajikan dalam LKPD masing-masing mengukur kemampuan indikator berpikir kreatif dengan rincian sebagai berikut : (1) Pada tahapan understanding, peserta didik disajikan sebuah fenomena fisis untuk dinyatakan kembali dalam bentuk pertanyaan. Dalam proses pengungkapan sebuah pertanyaan, peserta didik dilatih untuk melihat suatu fenomena fisis dari sudut pandang berbeda sehingga dapat mengaitkan hubungan antara dua variabel fisika. Pada proses pengungkapan pertanyaan inilah, kemampuan berpikir luwes peserta didik dilatih; (2) Pada tahapan planning, peserta didik diharapkan dapat mendesain, merangkai dan melakukan percobaan untuk menjawab pertanyaan pada bagian understanding. Kuantitas percobaan yang diharapkan dari peserta didik lebih dari satu. Dalam hal ini, ketika peserta didik dapat memaparkan desain percobaan lebih dari satu untuk menyelesaikan permasalahan maka telah melatih kemampuan berpikir luwesnya. Selanjutnya, pada saat menggambarkan desain percobaan peserta didik diharapkan menuliskan keterangan gambar secara lengkap. Tentunya proses ini melatih kemampuan berpikir elaboratif karena mampu memikirkan desain percobaan secara detail hingga pada cara penulisan data hasil percobaan yang mengikuti aturan angka penting. Selain itu, pada bagian desain percobaan peserta didik diharapkan memaparkan desainnya yang berbeda dengan desain yang sudah ada sebelumnya. Proses ini melatih kemampuan berpikir orisinal. Berdasarkan desain yang dibuat, peserta didik memaparkan langkah kerja secara runtut dan benar sehingga melatih 
kemampuan berpikir lancar. (3) Pada tahapan solving, peserta didik disajikan dua pertanyaan. Pertanyaan pertama dianggap dapat melatih kemampuan berpikir luwes karena berpikir lebih luas untuk menghubungkan antara fenomena yang diberikan dengan percobaan yang dilakukan. Pertanyaan kedua dianggap mampu melatih kemampuan berpikir elaboratif karena dalam memformulasikan persamaan fisika dibutuhkan pemahaman awal terkait persamaan yang digunakan secara detail dan benar. (4) Pada tahapan checking disajikan pertanyaan-pertanyaan dengan tujuan memeriksa kembali jawaban pada tahap sebelumnya. Dalam kegiatan ini dianggap mampu melatih kemampuan berpikir elaboratif karena peserta didik mampu memerinci bagian spesifik dari bagian umum (seperti rumusan masalah, desain percobaan dan penjabaran persamaan hukum pascal) secara benar.

Dengan demikian, berdasarkan hasil pengerjaan peserta didik dan tahapan problem solving dalam LKPD maka dapat disimpulkan bahwa LKPD Fisika berbasis problem solving cukup efektif untuk mengukur kemampuan berpikir kreatif peserta didik.

\section{SIMPULAN DAN SARAN}

\section{Simpulan}

Berdasarkan analisis data dan pembahasan dapat disimpulkan bahwa LKPD Fisika berbasis problem solving pada materi fluida statis memenuhi kriteria sangat valid dengan rata-rata $95 \%$, kriteria sangat praktis dengan rata-rata $86 \%$ respon peserta didik dan $85 \%$ respon guru mata pelajaran, serta cukup efektif digunakan untuk mengukur kemampuan berpikir kreatif peserta didik dengan rata-rata kemampuan berpikir kreatif sebesar 67 . Dengan demikian, LKPD Fisika berbasis problem solving layak digunakan dalam mengukur kemampuan berpikir kreatif peserta didik.

\section{Saran}

1. Bagi peneliti selanjutnya yang berminat mengkaji hal serupa diharapkan dapat melanjutkan pada tahapan keempat 4-D yaitu tahap penyebaran (dissiminate).

2. Diharapkan bagi peneliti selanjutnya dapat lebih mengkaji indikator kemampuan berpikir kreatif dari tahapan problem solving dalam konteks pembelajaran di kelas.

\section{DAFTAR PUSTAKA}

[1] Sani, Riduwan Abdullah. (2019). SOAL FISIKA HOTS. Jakarta : Bumi Aksara.

[2] Rohim \& Susanto. (2012). Penerapan Model Discovery Terbimbing Pada Pembelajaran Fisika Untuk Meningkatkan Kemampuan Berpikir Kreatif. UPEJ (Unnes Physics Education Journal), Vol 1 No. 1. https://doi.org/10.15294/upej.v1i1.775

[3] Supardi (2012). Peran Berpikir Kreatif dalam Pembelajaran Matematik. Jurnal Ilmiah Pendidikan MIPA-Universitas Indraprasta PGRI. Vol 2 No. 2, Hal 248-262.

http://dx.doi.org/10.30998/formatif.v2i $\underline{3.107}$

[4] Sahida. (2018). Pengembangan Lembar Kerja Peserta Didik Berbasis Problem Based Learning Berbantuan Komik untuk Meningkatkan Creative Thinking Skill Peserta Didik pada Materi Gerak Lurus. Jurnal Eksakta Pendidikan (Jep), Vol 2 No. 1. https://doi.org/10.24036/jep/vol2iss $1 / 145$.

[5] Fitriani, Gunawan, \& Sutrio. (2017). Berpikir Kreatif Dalam Fisika Dengan Pembelajaran Conceptual Understanding Procedures (CUPs) Berbantuan Lkpd. Jurnal Pendidikan Fisika Dan Teknologi, Vol 3. No.1. 
https://doi.org/10.29303/jpft.v3i1.319

[6] Nurliawaty, Mujasam, Yusuf, \& Widyaningsih. (2017). Lembar Kerja Peserta Didik (Lkpd) Berbasis Problem Solving Polya. JPI (Jurnal Pendidikan Indonesia), Vol 6 No.1. https://doi.org/10.23887/jpiundiksha.v6i1.9183

[7] Fadillah, (2016). Pengaruh Pembelajaran Problem Solving Terhadap Kemampuan Berpikir Kreatif Matematis Siswa. Volume 2 Nomer 1, Hal 1-8.

[8] Sugiyono. (2017). Metode penelitian pendidikan.

[9] Suharsimi Arikunto. (2010). Prosedur Peneltian Suatu Pendekatan Praktik. Rineka Cipta.

[10] Centaury. (2015). Pengembangan Perangkat Pembelajaran Fisika Berbasis Inkuiri Pada Materi Alat Optik Dan Indikator Dampak Terhadap Kompetensi Siswa Kelas X Sma. Jurnal Riset Fisika Edukasi Dan Sains, Vol 1 no. 2, Hal 80-91. https://doi.org/10.22202/jrfes.2015.v1i $\underline{2.1403}$

[11] Sriyanto, Agus. (2019), Teknik
Pengolahan Hasil Asesmen Penentuan Standar Asesmen, Teknik Pengolahan dengan Menggunakan Pendekatan Acuan Patokan (PAP) dan Acuan Norma (PAN). Jurnal Al-Luhab. Vol. 5 No. 2 Hal. 242-258. http://ejournal.kopertais4.or.id/matara man/index.php/allubab/article/view/39 $\underline{15}$

[12] Ikromi. (2018). Meningkatkan Kemampuan Berpikir Kreatif Matematis Siswa SMA Melalui Pembelajaran Open-Ended Pada Materi SPLTV. Jurnal Matematika Statistika Dan Komputasi, Vol. 15 No. 2 https://doi.org/10.20956/jmsk.v15i2.57 $\underline{19}$

[13] Retnawati. (2016). Analisis Kuantitatif Instrumen Penelitian. (Panduan Peneliti, Mahasiswa, dan Psikometrian. Yogyakarta : Parama Publishing

[14] Alfiani. (2017). Kepraktisan Dan Kefektifan Modul Pembelajaran Bilingual Berbasis Komputer. Jurnal Kependidikan, Vol 1 no. 1 Hal. 12-23 